\title{
Mendeteksi Kecurangan Laporan Keuangan Menggunakan Model Beneish
}

\author{
Irsutami $^{\text {a, }}$, and Rizky Sapriadi ${ }^{\mathrm{b}}$ \\ ${ }^{a}$ Politeknik Negeri Batam,tami@polibatam.ac.id, Indonesia \\ boliteknik Negeri Batam, rizkysapriadi60@gmail.com, Indonesia
}

\begin{abstract}
This study aimed to determine the effect of eight Beneish variables on earnings management in detecting fraudulent financial statements in property, real estate and building construction companies listing on the Indonesia Stock Exchange in 2014 - 2018. The population in this study is 80 companies in property, real estate and building construction sector. The sampling technique uses purposive sampling. The method of data collection used archival data collection techniques in the database. Data analysis used descriptive analysis using the Beneish ratio index, the classic assumption test and simple linear regression analysis. The results showed that DSRI (Days Sales in Receivable Index), SGI (Sales Growth Index), DEPI (Depreciation Index), TATA (Total Accrual to Total Assets Index), and LVGI (Leverage Index) variables significantly influence earnings management in detecting fraudulent financial statements in sample companies. While the GMI (Gross Margin Index), AQI (Asset Quality Index), and SGAI (Selling, General and Administrative Index) no significant effect on earnings management in detecting fraudulent financial statements in sample companies.
\end{abstract}

Keywords: Beneish ratio index, Earnings management, Detection of financial statement fraud.

${ }^{*}$ Corresponding author. tami@polibatam.ac.id 


\section{Pendahuluan}

Laporan keuangan perusahaan merupakan proses akhir dalam akuntansi yang bertujuan menginformasikan tentang jenis dan jumlah aktiva, kewajiban dan modal, pendapatan dan biaya, kinerja manajemen serta informasi keuangan lainnya tentang perusahaan pada periode tertentu (Kasmir, 2013). Laporan keuangan yang baik akan sangat bermanfaat bagi pihak-pihak yang menggunakan laporan keuangan. Bagi pihak inernal, laporan keuangan akan digunakan untuk mengevaluasi kinerja dan merumuskan strategi yang tepat bagi kelangsungan perusahaan. Bagi pihak eksternal perusahaan, laporan keuangan menjadi dasar dalam memberikan keputusan-keputusan ekonomi seperti; dasar memberikan pinjaman modal, berinvestasi, penetapan pajak, serta keputusan ekonomi lainnya.

Sebuah laporan keuangan apabila terdapat salah saji di dalamnya hanya terdapat dua faktor, yaitu sebagai akibat dari kekeliruan dan akibat dari kecurangan (Tuanakotta, 2013). Tindakan kecurangan pada laporan keuangan tentu saja akan merugikan para pengguna laporan keuangan. Bagi manajemen internal perusahaan, keputusan yang diambil atas dasar laporan keuangan yang dimanipulasi akan menghasilkan keputusan yang tidak sesuai dengan kebutuhan perusahaan. Sedangkan bagi investor maupun kreditor yang membantu modal perusahaan akan mengalami kerugian apabila dividend dan pelunasan utang yang tidak sesuai dengan perencanaan.

Menurut Skousen, Smith \& Wright (2009), situasi yang merupakan faktor terjadinya tindakan kecurangan disebut dengan Istilah fraud triangle. Segitiga fraud ini terdiri dari tekanan (pressure), kesempatan (opportunity) serta rasionalisasi (rationalization). Kecurangan laporan keuangan yang tidak terdeteksi akan menimbulkan kerugian bagi para pengguna laporan keuangan. Hal ini lah yang menjadi alasan bahwa penting untuk melakukan pendeteksian terhadap laporan keuangan. Dengan mengetahui kecurangan laporan keuangan, para pengguna laporan keuangan mampu untuk memberikan keputusan-keputusan ekonomi dengan lebih baik.

Penelitian ini merupakan replikasi dari penelitian yang dilakukan oleh Repousis (2016). Perbedaan dari penelitian sebelumnya adalah sampel yang digunakan berupa data perusahaan sector property, real estate dan konstruksi bangunan yang listing di Bursa Efek
Indonesia periode 2017 - 2018. Penelitian ini menguji signifikansi antara delapan variabel Beneish dengan manajemen laba sesuai dengan penelitian Repousis (2016).

Rumusan masalah dalam penelitian ini adalah apakah terdapat hubungan yang signifikan antara DSRI, GMI, AQI, SGI, DEPI, SGAI, TATA dan LVGI dan manajemen laba dalam mendeteksi kecurangan laporan keuangan. Tujuan penelitian ini adalah menguji hubunan antara DSRI, GMI, AQI, SGI, DEPI, SGAI, TATA dan LVGI dan manajemen laba. Manfaat dalam penelitian ini secara teori sebagai penambah wawasan dan pengetahuan kepada pihak-pihak yang melakukan penelitian tentang deteksi kecurangan pada laporan keuangan khususnya dengan menggunakan model Beneish. Hasil penelitian ini juga diharapkan bermanfaat secara praktis bagi pihak-pihak yang merupakan pengguna laporan keuangan. Bagi manajemen perusahaan, penelitian ini dapat di jadikan peringatan agar tidak melakukan kecurangan dalam menyajikan laporan keuangan perusahaan. Penelitian ini juga dapat digunakan oleh Investor dan Kreditor untuk meminjamkan modal dengan mengetahui perusahaan manakah yang tergolong manipulator maupun non manipulator. Manfaat praktis lainnya adalah dapat digunakan oleh regulator dalam menentukan aturan yang tepat serta melakukan pengawasan terhadap perusahaan yang listing di Bursa Efek Indonesia.

\section{Kerangka Teoritis dan Pengembangan Hipotesis}

\section{Teori Agensi}

Penelitian ini didukung oleh teori agensi yang melambangkan situasi yang bertolak belakang dalam masalah kepentingan antara manajemen di sebuah perusahaan dan para pemegang saham yang nantinya ditakutkan akan menimbulkan kecurangan. Menurut Jensen dan Meckling (1976), hubungan keagenan adalah suatu kontrak antara pihak principal selaku pemilik modal dengan pihak agen selaku manajer. Sebagai agen, manajer dituntut menjalankan kewajibannya untuk memaksimalkan pengembalian atas modal yang diberikan oleh investor selaku principal. Disisi lain, manajer juga memiliki kepentingan untuk memaksimalkan kesejahteraan mereka sendiri. Perbedaan kepentingan antara agen dan principal inilah yang seringkali memicu terjadinya kecurangan. Manajer mamanipulasi laporan keuangan agar terlihat baik dan menarik 
investor untuk menanamkan modal nya di perusahaan.

\section{Kecurangan Laporan Keuangan}

Menurut Ikatan Akuntan Indonesia (IAI) (2012), kecurangan akuntansi merupakan salah saji yang timbul dari kecurangan dalam pelaporan keuangan yaitu salah saji atau penghilangan secara sengaja jumlah atau pengungkapan dalam laporan keuangan untuk mengelabui pemakai laporan keuangan. Sedangkan menurut The Association of Fraud Examiners (ACFE) (2016) kecurangan pada laporan keuangan merupakan tindakan kecurangan yang dilakukan oleh pihak manajemen perusahaan dalam penyajian laporan keuangan yang sifatnya material sehingga dapat menyesatkan investor dalam memberikan keputusan ekonomi.

\section{Beneish Ratio Index}

Penggolongan perusahaan sebagai manipulator atau non manipulator diperlukan sebuah model perhitungan untuk mendeteksi pergerakan tidak wajar pada laporan keuangan, yakni Beneish M-Score Model (Repousis, 2016). Model ini menggunakan delapan variabel berupa rasio perhitungan keuangan untuk mengidentifikasikan apakah perusahaan memanipulasi pendapatan dalam laporan keuangan. Indeks rasio Beneish dapat dilihat dalam tabel berikut :

1) DSRI (days sales in receivable Index)

Tabel 1

Indeks Rasio Beneish DSRI

\begin{tabular}{ll}
\hline \multicolumn{1}{c}{ Indeks } & \multicolumn{1}{c}{ Keterangan } \\
\hline$\leq 1,031$ & Non Manipulators \\
$1,031<$ indeks $<1,465$ & Grey \\
$\geq 1,465$ & Manipulators \\
\hline Sumber: Beneish (1999) &
\end{tabular}

2) GMI (gross margin Index)

Tabel 2

Indeks Rasio Beneish GMI

\begin{tabular}{ll}
\hline \multicolumn{1}{c}{ Indeks } & \multicolumn{1}{c}{ Keterangan } \\
\hline$\leq 1,014$ & Non Manipulators \\
$1,014<$ indeks $<1,193$ & Grey \\
$\geq 1,193$ & Manipulators \\
\hline
\end{tabular}

3) $\mathrm{AQI}$ (asset quality Index)

Tabel 3

Indeks Rasio Beneish DSRI

\begin{tabular}{ll}
\hline \multicolumn{1}{c}{ Indeks } & \multicolumn{1}{c}{ Keterangan } \\
\hline$\leq 1,039$ & Non Manipulators \\
$1,039<$ indeks $<1,254$ & Grey \\
$\geq 1,254$ & Manipulators \\
\hline Sumber: Beneish (1999) &
\end{tabular}

4) SGI (sales growth Index)

Tabel 4

Indeks Rasio Beneish DSRI

\begin{tabular}{ll}
\hline \multicolumn{1}{c}{ Indeks } & \multicolumn{1}{c}{ Keterangan } \\
\hline$\leq 1,134$ & Non Manipulators \\
$1,134<$ indeks $<1,607$ & Grey \\
$\geq 1,607$ & Manipulators \\
\hline Sumber: Beneish $(1999)$ &
\end{tabular}

Sumber: Beneish (1999)

5) DEPI (depreciation Index)

Tabel 5

Indeks Rasio Beneish DSRI

\begin{tabular}{ll}
\hline \multicolumn{1}{c}{ Indeks } & \multicolumn{1}{c}{ Keterangan } \\
\hline$\leq 1,001$ & Non Manipulators \\
$1,001<$ indeks $<1,077$ & Grey \\
$\geq 1,077$ & Manipulators \\
\hline
\end{tabular}

Sumber: Beneish (1999)

6) SGAI (selling, general and administrative expenses Index)

Tabel 6

Indeks Rasio Beneish DSRI

\begin{tabular}{ll}
\hline \multicolumn{1}{c}{ Indeks } & \multicolumn{1}{c}{ Keterangan } \\
\hline$\leq 1,041$ & Non Manipulators \\
$1,041<$ indeks $<1,054$ & Grey \\
$\geq 1,054$ & Manipulators \\
\hline Sumber: Beneish (1999) &
\end{tabular}

7) TATA (total accruals to total assets Index)

Tabel 7

Indeks Rasio Beneish DSRI

\begin{tabular}{ll}
\hline \multicolumn{1}{c}{ Indeks } & \multicolumn{1}{c}{ Keterangan } \\
\hline$\leq 0,018$ & Non Manipulators \\
$0,018<$ indeks $<0,031$ & Grey \\
$\geq 0,031$ & Manipulators \\
\hline Sumber: Beneish (1999) &
\end{tabular}

Sumber: Beneish (1999) 
8) LVGI (leverage Index)

Tabel 8

Indeks Rasio Beneish DSRI

\begin{tabular}{ll}
\hline \multicolumn{1}{c}{ Indeks } & \multicolumn{1}{c}{ Keterangan } \\
\hline$\leq 1,037$ & Non Manipulators \\
$1,037<$ indeks $<1,111$ & Grey \\
$\geq 1,111$ & Manipulators \\
\hline Sumber: Beneish (1999) &
\end{tabular}

Sumber: Beneish (1999)

Berdasarkan rumusan masalah, maka penelitian ini memiliki beberapa hipotesis diantaranya sebagai berikut :

Pengaruh Days Sales in Receivable Index (DSRI) terhadap Manajemen Laba

Peningkatan besar dalam piutang dagang sebagai persentase dari penjualan menunjukkan pernyataan piutang dan penjualan yang berlebihan dalam meningkatkan pendapatan perusahaan (Beneish, 1999). Hasil Penelitian Repousis (2016) juga menunjukkan bahwa terdapat hubungan yang signifikan antara DSRI dan manajemen laba. Berdasarkan penelitian tersebut maka peneliti merumuskan hipotesis pertama sebagai berikut.

H1: DSRI berpengaruh signifikan terhadap manajemen laba

Pengaruh Gross Margin Index (GMI) terhadap Manajemen Laba

Menurut Beneish (1999) perusahaan dengan profitabilitas yang lebih lemah cenderung terlibat dalam memanipulasi laba. Hasil Penelitian Repousis (2016) juga menunjukkan bahwa terdapat hubungan yang signifikan antara GMI dan manajemen laba. Berdasarkan penelitian tersebut maka peneliti merumuskan hipotesiS kedua sebagai berikut.

H2: GMI berpengaruh signifikan terhadap manajemen laba

Pengaruh Asset Quality Index (AQI) terhadap Manajemen Laba

Peningkatan proporsi aset perusahaan mengindikasikan adanya peningkatan upaya menunda pembiayaan (Beneish, 1999). Hasil Penelitian Repousis (2016) juga menunjukkan bahwa terdapat hubungan yang signifikan antara AQI dan manajemen laba. Berdasarkan penelitian tersebut maka peneliti merumuskan hipotesis ketiga sebagai berikut,
H3: AQI berpengaruh signifikan terhadap manajemen laba

Pengaruh Sales Growth Index (SGI) terhadap Manajemen Laba

Menurut Beneish (1999) kebutuhan akan pembiayaan yang rendah dapat memotivasi terjadinya manipulasi penjualan. Hasil Penelitian Repousis (2016) menunjukkan bahwa terdapat hubungan yang signifikan antara SGI dan manajemen laba. Berdasarkan penelitian tersebut maka peneliti merumuskan hipotesis keempat sebagai berikut,

H4: SGI berpengaruh signifikan terhadap manajemen laba.

Pengaruh Depreciation Index (DEPI) terhadap Manajemen Laba

Laju depresiasi yang diperlambat cenderung akan meningkatkan pendapatan (Beneish, 1999). Hasil Penelitian Repousis (2016) menunjukkan bahwa tidak terdapat hubungan yang signifikan antara DEPI dan manajemen laba. Perbedaan hasil penelitian tersebut disebabkan oleh perbedaan sampel dan waktu penelitian. Namun, teori agensi mendukung pendapat Beneish dimana manajemen akan memanipulasi pendapatan perusahaan agar menarik investor meskipun dengan memanipulasi depresiasinya. Berdasarkan hal tersebut maka peneliti merumuskan hipotesis kelima sebagai berikut,

H5: DEPI berpengaruh signifikan terhadap manajemen laba.

Pengaruh Selling, General and Administratif Index (SGAI) terhadap Manajemen Laba

Beneish (1999) mengatakan bahwa nilai biaya penjualan, umum dan administratif yang lebih besar atau sama menunjukkan peningkatan pengeluaran pemasaran yang akan meningkatkan penjualan. Hasil Penelitian Repousis (2016) menunjukkan bahwa terdapat hubungan yang signifikan antara SGAI dan manajemen laba. Berdasarkan penelitian tersebut maka peneliti merumuskan hipotesis keenam sebagai berikut,

H6: SGAI berpengaruh signifikan terhadap manajemen laba.

Pengaruh Total Accrual to Total Assets Index (TATA) terhadap Manajemen Laba

TATA menunjukkan volume penghasilan yang dihasilkan dari pendapatan akrual, bukan dari uang 
tunai (Beneish, 1999). Hasil Penelitian Repousis (2016) menunjukkan bahwa tidak terdapat hubungan yang signifikan antara TATA dan manajemen laba. Namun, teori agensi mendukung pendapat Beneish dimana manajemen akan memanipulasi pendapatan akrual perusahaan agar investor tertarik berinvestasi di perusahaan. Berdasarkan hal tersebut maka peneliti merumuskan hipotesis ketujuh sebagai berikut,

H7: TATA berpengaruh signifikan terhadap manajemen laba.

\section{Pengaruh Leverage Index (LVGI) terhadap Manajemen Laba}

Menurut Beneish (1999), peningkatan dalam proporsi hutang memiliki kemungkinan melakukan pelanggaraan perjanjian hutang. Hasil Penelitian Repousis (2016) menunjukkan bahwa tidak terdapat hubungan yang signifikan antara LVGI dan manajemen laba. Namun, teori agensi mendukung pendapat Beneish dimana manajemen akan memanipulasi hutang perusahaan agar keuangan perusahaan dinilai baik-baik saja dan menarik bagi investor. Berdasarkan hal tersebut maka peneliti merumuskan hipotesis kedelapan sebagai berikut,

H8: LVGI berpengaruh signifikan terhadap manajemen laba.

\section{Metode Penelitian}

\section{Definisi Operasional Variabel dan Pengukuran}

Penelitian ini menggunakan dua variabel, yaitu variabel bebas (independent variable) dan variabel terikat (dependent variable). Variabel independen yang digunakan dalam penelitian ini sesuai dengan Beneish Ratio Index yaitu :

1. DSRI (days sales in receivable index), yaitu hari penjualan dalam indeks piutang. Formula perhitungan DSRI adalah sebagai berikut :

$$
\text { DSRI }=\frac{\text { Net Receivable }_{t} \div \text { Sales }_{t}}{\text { Net Receivable }_{t-1} \div \text { Sales }_{t-1}}
$$

Sumber: Beneish (1999)

2. GMI (gross margin index), yaitu indeks margin kotor. Formula perhitungan GMI adalah sebagai berikut :
GMI $=\frac{\left(\left(\text { Sales }_{t-1}-\text { COGS }_{t-1}\right) \div \text { Sales }_{t-1}\right)}{\left(\left(\text { Sales }_{t}-\text { COGS }_{t}\right) \div \text { Sales }_{t}\right)}$

Sumber: Beneish (1999)

3. AQI (asset quality index), yaitu indeks kualitas aset. Formula perhitungan AQI adalah sebagai berikut :

$$
A Q I=\frac{\left(1-\left(C_{t}+P P E_{t}\right) \div T A_{t}\right)}{\left(1-\left(\mathrm{CA}_{t-1}+P P E_{t-1}\right) \div T A_{t-1}\right)}
$$

Sumber: Beneish (1999)

4. SGI (sales growth index), yaitu indeks pertumbuhan penjualan. Formula perhitungan SGI adalah sebagai berikut :

$\mathrm{SGI}=\frac{\text { Sales }_{\mathrm{t}}}{\text { Sales }_{\mathrm{t}-1}}$

Sumber: Beneish (1999)

5. DEPI (depreciation index), yaitu indeks depresiasi. Formula perhitungan DEPI adalah sebagai berikut :

DEPI $=\frac{\left(\text { Depreciation }_{\mathrm{t}-1} \div\left(\mathrm{PPE}_{\mathrm{t}-1}+\text { Depreciation }_{\mathrm{t}-1}\right)\right)}{\left(\text { Depreciation }_{\mathrm{t}}+\left(\mathrm{PPE}_{\mathrm{t}}+\text { Depreciation }_{\mathrm{t}}\right)\right)}$

Sumber: Beneish (1999)

6. SGAI (selling, general and administrative expenses index), yaitu indeks penjualan serta beban umum dan administrasi. Formula perhitungan SGAI adalah sebagai berikut :

$S G A I=\frac{\left(\text { SGA Expense }_{t} \div \text { Sales }_{t}\right)}{\left(\text { SGA Expense }_{t-1} \div \text { Sales }_{t-1}\right)}$

Sumber: Beneish (1999)

7. TATA (total accruals to total assets index), yaitu indeks total akrual ke total aset. Formula perhitungan TATA adalah sebagai berikut :

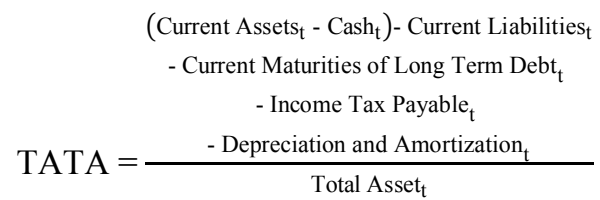

Sumber: Beneish (1999) 
8. LVGI (leverage index) yaitu indeks leverage. Formula perhitungan LVGI adalah sebagai berikut :

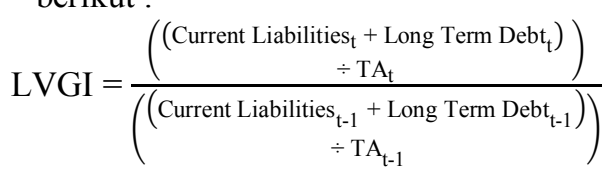

Sumber: Beneish (1999)

Keterangan:

Net Receivable

Net Receivable t-1 $_{\text {. }}$

Sales $_{\mathrm{t}}$

Sales $_{\mathrm{t}-1}$

COGS $_{\mathrm{t}}$

COGS $_{\mathrm{t}-1}$

$\mathrm{CA}_{\mathrm{t}}$

$\mathrm{PPE}_{\mathrm{t}}$

$\mathrm{PPE}_{\mathrm{t}-1}$

$\mathrm{TA}_{\mathrm{t}}$

$\mathrm{TA}_{\mathrm{t}-1}$

Depreciation $_{\mathrm{t}}$

Depreciation $_{\mathrm{t}-1}$

SGA Expense $_{t}$

SGA Expense Ex-1
Piutang bersih tahun sekarang

. Piutang bersih tahun sebelumnya

Penjualan tahun sekarang

Penjualan tahun sebelumnya

. Harga pokok penjualan tahun sekarang Harga pokok penjualan : tahun sebelumnya

Aset lancar tahun sekarang Property, Plant, and

. Equipment tahun sekarang Property, Plant, and

. Equipment tahun sebelumnya

Total aset tahun

: sekarang

Total aset tahun

: sebelumnya

Penyusutan tahun

: sekarang Penyusutan tahun

: sebelumnya Penjualan, beban umum

dan administrasi tahun sekarang

Penjualan, beban umum dan

: administrasi tahun sebelumnya

\begin{tabular}{|c|c|}
\hline Current Asset ${ }_{t}$ & $\begin{array}{l}\text { Aset lancar tahun } \\
: \text { sekarang }\end{array}$ \\
\hline $\mathrm{Cash}_{\mathrm{t}}$ & : Kas tahun sekarang \\
\hline Current Liabilities $_{t}$ & $\begin{array}{l}\text { Hutang lancar tahun } \\
: \text { sekarang }\end{array}$ \\
\hline $\begin{array}{l}\text { Current Maturities of } \\
\text { Long Term Debt }\end{array}$ & $\begin{array}{l}\text { Hutang jangka panjang } \\
\text { : jatuh tempo saat ini }\end{array}$ \\
\hline Income Tax Payable P $_{t}$ & $\begin{array}{l}\text { Hutang pajak } \\
\text { : penghasilan tahun } \\
\text { sekarang }\end{array}$ \\
\hline Total Asset ${ }_{t}$ & $\begin{array}{l}\text { Total aset tahun } \\
: \text { sekarang }\end{array}$ \\
\hline Long Term Debt ${ }_{\mathrm{t}-1}$ & $\begin{array}{l}\text { Hutang jangka panjang } \\
: \text { tahun sebelumnya }\end{array}$ \\
\hline
\end{tabular}

Variabel dependen dalam penelitian ini adalah manajemen laba (earning management). Formula untuk menentukan manajemen laba sesuai dengan Indeks Beneish adalah sebagai berikut :

$$
\begin{aligned}
& \text { Beneish M-Score }=-4,84+(0,92 \times \text { DSRI })+ \\
& (0,528 \times \text { GMI })+(0,404 \times \text { AQI }+(0,892 \times \text { SGI })+ \\
& (0,115 \times \text { DEPI })-(0,172 \times \text { SGAI })+(4,679 \times \\
& \text { TATA })-(0,327 \times \text { LVGI })
\end{aligned}
$$

Jenis dan Sumber data

Penelitian ini menggunakan data kuantitatif dengan jenis skala pengukuran data rasio. Data yang digunakan merupakan data sekunder yang bersumber dari BEI melalui situs resmi www.idx.co.id selama periode 2014 - 2018. Data yang diperoleh tersebut dihitung menggunakan rumus Beneish M-Score sehingga menjadi rasio-rasio yang kemudian dianalisis dengan alat analisis regresi linier sederhana.

\section{Lokasi dan Obyek Penelitian}

Bursa Efek Indonesia (BEI) merupakan lokasi dari penelitian yang tentunya terkait dengan data yang dibutuhkan untuk penelitian. Obyek dari penelitian ini adalah perusahaan property, real estate dan konstruksi bangunan yang terindikasi melakukan kecurangan laporan keuangan dengan perusahaan yang tidak terindikasi melakukan kecurangan laporan keuangan yang ditentukan menggunakan model Beneish M-Score. 


\section{Teknik Penetapan Jumlah Sampel}

Peneliti menggunakan perusahaan yang terdaftar di BEI sebagai populasi dalam penelitian ini. Sampel yang digunakan adalah perusahaan property, real estate dan konstruksi bangunan yang menerbitkan laporan keuangan tahunan periode $2014-2018$ yang diperoleh melalui situs resmi BEI yaitu www.idx.co.id dan terindikasi melakukan kecurangan laporan keuangan berdasarkan perhitungan rumus Beneish M-Score.

\section{Teknik Penarikan Sampel}

Peneliti menggunakan teknik pengambilan sampel secara purposive sampling di dalam penelitian ini, dimana penarikan sampel dilakukan dengan beberapa kriteria yang dibutuhkan untuk dapat dijadikan sampel penelitian. Berikut kriteria-kriteria yang digunakan dalam penelitian ini :

1. Perusahaan di dalam menyajikan sebuah laporan keuangan menggunakan satuan nilai mata uang rupiah;

2. Perusahaan mempunyai data yang lengkap dan selaras dengan komponen yang dijadikan pengukuran pada rasio-rasio Beneish Ratio Index yang dijadikan variabel dalam penelitian ini.

3. Perusahaan yang terindikasi melakukan kecurangan laporan keuangan yang terdaftar di BEI berdasarkan perhitungan rumus Beneish MScore dengan periode laporan keuangan tahun $2014-2018$.

\section{Teknik Pengumpulan Data}

Teknik pengumpulan data dalam penelitian ini menggunakan teknik pengumpulan data arsip di basis data. Data yang digunakan dalam penelitian ini berupa laporan keuangan perusahaan property, real estate dan konstruksi bangunan yang listing di Bursa Efek Indonesia (BEI) tahun 2017. Data diperoleh dari mengunduh dokumen laporan keuangan emiten dalam bentuk soft file di website Bursa Efek Indonesia (BEI) www.idx.co.id.

\section{Teknik Pengolahan Data}

Langkah-langkah pengolahan data yang digunakan dalam penelitian ini adalah sebagai berikut:
a. Menentukan variabel-variabel yang akan dimasukkan dalam tabel silang atau tabel frekuensi.

b. Melakukan tabulasi data dengan mengambil informasi yang dibutuhkan pada laporan keuangan ke dalam worksheet pada MS Excel.

c. Menghitung Rasio Index perusahaan/Index hitung dengan menggunakan formula masingmasing variabel berdasarkan data yang sudah ditabulasikan.

d. Membandingkan Index hitung dengan Beneish Ratio Index.

e. Mengelompokkan perusahaan sesuai dengan kategorinya, sebagai perusahaan manipulator, Grey, atau non manipulator.

f. Melakukan pemeriksaan kelayakan data dengan uji asumsi klasik.

g. Melakukan analisis regresi linier sederhana dan pengujian hipotesis data panel menggunakan Aplikasi Eviews 9.

\section{Teknik Analisis Data}

\section{Analisis Statistik Deskriptif}

Penelitian ini menggunakan analisis statistik deskriptif untuk mengetahui bagaimana posisi perusahaan dalam tingkatan rasio keuangan perusahaan. Posisi perusahaan digambarkan dengan digolongkannya perusahaan sebagai manipulator, grey atau non manipulator.

\section{Uji Asumsi Klasik}

Menurut Ghozali (2013) uji asumsi klasik perlu dilakukan sebelum menganalisis data menggunakan analisis regresi liniear untuk memberikan kepastian bahwa persamaan regresi memiliki ketepatan dalam estimasi, konsisten dan tidak bias. Adapun beberapa uji asumsi klasik yang diperlukan dalam penelitian ini adalah sebagai berikut:

1. Uji Normalitas

Pengujian apakah data berdistribusi normal atau tidak menggunakan aplikasi Eviews 9 dengan melakukan uji statistik Jarque-Bera. Residual berdistribusi normal jika memiliki nilai probabilitas $>0,05$ (Ghozali, 2013).

2. Uji Multikolinieritas

Menurut Ghozali (2013), pengujian adanya korelasi antar variabel bebas dalam model regresi (multikolinieritas) dilakukan dengan cara melihat nilai VIF masing-masing variabel independen, jika nilai VIF $<10$, 
maka dapat disimpulkan data bebas dari gejala multikolinieritas.

3. Uji Heterokedastisitas

Pengujian ketidaksamaan variance dari residual satu pengamatan ke pengamatan yang lain (heterokedastisitas) pada penelitian ini menggunakan uji BreuschPagan-Godfrey dimana probabilitas dari Chi Square pada Obs*R-Squared harus lebih besar dari 0,05 agar model regresi bersifat Homokedastisitas, atau bebas dari gejala Heterokedastisitas (Ghozali, 2013).

4. Uji Autokorelasi

Menurut Ghozali (2013), pengujian untuk melihat apakah terjadi korelasi antara suatu periode $\mathrm{t}$ dengan periode sebelumnya (autokorelasi) dapat menggunakan uji Durbin-Watson (DW test). Data tidak mengalami autokorelasi positif atau negatif tersebut bila hasil uji Durbin-Watson (d) sesuai dengan perbandingan $\mathrm{dU}<\mathrm{d}<$ (4dU). dU dapat dilihat pada tabel DurbinWatson pada signifikansi 5\% dengan rumus (k:N). k merupakan jumlah variable bebas, dan $\mathrm{N}$ merupakan jumlah sampel dalam satu variabel.

\section{Analisis Regresi Linier Sederhana}

Analisis regresi linier sederhana ini digunakan untuk menguji pengaruh dari masing-masing variabel bebas terhadap variabel terikat. Hasil dari regresi linier sederhana kemudian akan digunakan untuk menguji hipotesis penelitian. Adapun pengujian hipotesis dilakukan dengan melakukan uji $\mathrm{t}$ dan koefisien determinasi (adjusted $R$ square).

\section{Hasil}

\section{Hasil pengolahan data yang terkumpul}

Penelitian ini menggunakan data sekunder yang berupa laporan keuangan perusahaan-perusahaan sektor property, real estate dan konstruksi bangunan yang listing di Bursa Efek Indonesia yang diperoleh melalui situs www.idx.co.id periode 2014 - 2018 . Populasi penelitian berjumlah 80 perusahaan.
Adapun hasil seleksi sampel menggunakan metode purposive sampling di dalam penelitian ini disajikan pada tabel di bawah ini:

Tabel 9

Hasil Seleksi Sampel

\begin{tabular}{lcc}
\hline \multicolumn{1}{c}{ Keterangan } & Jumlah & Persentase \\
\hline Jumlah Populasi Awal & 80 & $100 \%$ \\
Tidak sesuai Kriteria 1: & & \\
Tidak menggunakan satuan nilai & $(0)$ & $(0 \%)$ \\
mata uang rupiah. & & \\
Tidak sesuai Kriteria 2: & & $(8,75 \%)$ \\
Perusahaan tidak mempunyai \\
data yang lengkap dan selaras \\
dengan Beneish Ratio Index \\
$\begin{array}{l}\text { Tidak sesuai Kriteria 3: } \\
\text { Perusahaan yang tidak terindikasi } \\
\text { melakukan kecurangan laporan } \\
\text { keuangan }\end{array}$ \\
$\begin{array}{l}\text { Jumlah Sampel Perusahaan yang } \\
\text { memenuhi kriteria }\end{array}$
\end{tabular}

\section{Statistik Deskriptif}

Data statistik deskriptif digambarkan dalam tabel 10, Tabel 11 dan Tabel 12. Berdasarkan rumus rasio Indeks Beneish, perusahaan yang tergolong Non Manipulator memiliki rasio manajemen laba rata-rata lebih kecil dari -2,46 (tabel 12). Sedangkan perusahaan yang tergolong manipulator memiliki memiliki rasio manajemen laba rata-rata lebih besar dari -2,46 (tabel 10).

Tabel 9

Statistik Deskriptif perusahaan Manipulator $(\mathrm{N}=16)$

\begin{tabular}{llllll}
\hline \multicolumn{1}{c}{ Index } & Mean & Median & S. Dev & Min. & Max. \\
\hline DSRI & 1.1056 & 0.9531 & 0.6626 & 0.0088 & 3.2214 \\
GMI & 1.0697 & 1.0065 & 0.3108 & 0.4636 & 1.9637 \\
AQI & 1.1235 & 0.9998 & 0.5734 & 0.0008 & 3.1972 \\
SGI & 1.0780 & 1.0179 & 0.5541 & 0.0877 & 3.9023 \\
DEPI & 1.0411 & 0.9323 & 0.6743 & 0.0249 & 3.8720 \\
SGAI & 1.2613 & 1.0797 & 0.6962 & 0.2012 & 3.5616 \\
LVGI & 1.0857 & 1.0410 & 0.5740 & 0.0780 & 4.8073 \\
TATA & 0.1954 & 0.1776 & 0.2590 & -0.2934 & 0.8896 \\
$\begin{array}{l}\text { Manajemen } \\
\text { Laba }\end{array}$ & -1.3807 & -1.5640 & 1.5928 & -4.5664 & 2.8455 \\
\hline $\begin{array}{l}\text { Sumber: Data diolah sendiri, } 2019 \\
\text { Sumber }\end{array}$ & & & &
\end{tabular}


Tabel 10

Statistik Deskriptif perusahaan Non Manipulator $(\mathrm{N}=51)$

\begin{tabular}{lccccc}
\hline \multicolumn{1}{c}{ Index } & Mean & Median & S. Dev & Min. & Max. \\
\hline DSRI & 1.1074 & 1.0165 & 0.6370 & 0.0024 & 5.2481 \\
GMI & 1.0099 & 0.9993 & 0.1597 & 0.5174 & 1.8804 \\
AQI & 1.0333 & 0.9958 & 0.4072 & -0.7784 & 5.2809 \\
SGI & 1.0373 & 1.0104 & 0.2809 & 0.2828 & 2.1015 \\
DEPI & 1.0219 & 0.9785 & 0.4116 & 0.0240 & 3.3067 \\
SGAI & 1.0640 & 1.0114 & 0.3693 & 0.0031 & 3.3494 \\
LVGI & 0.9738 & 0.9932 & 0.1975 & 0.0445 & 1.7817 \\
TATA & - & -0.0315 & 0.2968 & -2.0497 & 0.6247 \\
Manajemen & - & & & & \\
Laba & 2.4614 & -2.4477 & 1.5621 & -11.3388 & 1.2698 \\
& & & & & \\
\hline
\end{tabular}

Sumber : Data diolah sendiri, 2019

\section{Hasil Uji Asumsi Klasik}

\section{Uji Normalitas}

Data berdistribusi normal bila probabilitas uji statistik Jarque-Bera Test $>0,05$. Hasil uji statistik Jarque-Bera Test dengan menggunakan Aplikasi Eviews 9 adalah sebagai berikut :

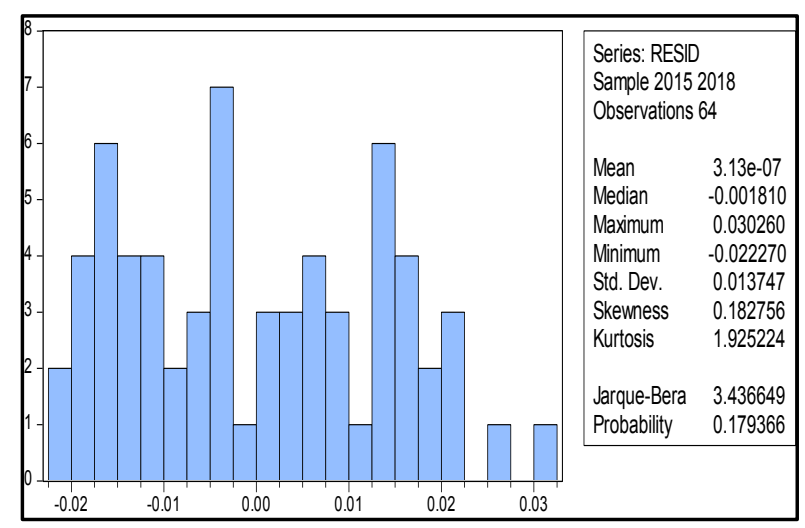

Gambar 1 Hasil Uji Normalitas Jarque-Bera

Hasil uji normalitas tersebut menunjukkan bahwa probabilitas uji statistik Jarque-Bera sebesar 0,1794 yang menunjukkan bahwa data berdistribusi normal.

\section{Uji Multikolonieritas}

Data bebas dari gejala multikolinieritas bila hasil dari VIF $<10$. Hasil uji multikolinieritas dengan menggunakan Aplikasi Eviews 9 adalah sebagai berikut :
Tabel 11

Hasil Uji Multikolonieritas

\begin{tabular}{cccc}
\hline Variable & $\begin{array}{c}\text { Coefficient } \\
\text { Variance }\end{array}$ & $\begin{array}{c}\text { Uncentered } \\
\text { VIF }\end{array}$ & $\begin{array}{c}\text { Centered } \\
\text { VIF }\end{array}$ \\
\hline & & & \\
C & 0.321310 & 35.25240 & NA \\
X1 & 0.017510 & 2.885520 & 1.092130 \\
X2 & 0.048277 & 7.436239 & 1.066315 \\
X3 & 0.034280 & 5.892169 & 1.193093 \\
X4 & 0.055625 & 9.003986 & 1.746599 \\
X5 & 0.025508 & 4.199079 & 1.226342 \\
X6 & 0.029314 & 6.731915 & 1.609306 \\
X7 & 0.154135 & 1.762077 & 1.116648 \\
X8 & 0.032725 & 5.296847 & 1.135177 \\
\hline
\end{tabular}

Hasil uji multikolinieritas tersebut menunjukkan bahwa semua VIF dari masing-masing variabel bernilai lebih kecil dari 10. Hal ini menunjukkan bahwa data bebas dari gejala multikolinieritas.

\section{Uji Heterokedastisitas}

Data tidak mengalami heteroskedastisitas apabila probabilitas chi square $>0,05$. Hasil uji heteroskedastisitas dengan menggunakan aplikasi Eviews 9 adalah sebagai berikut :

Tabel 12

Tabel Hasil Uji Breusch-Pagan-Godfrey

\begin{tabular}{|llll|}
\hline \multicolumn{4}{|l|}{ Heteroskedasticity Test: Breusch-Pagan-Godfrey } \\
\hline \hline F-statistic & 31.70868 & Prob. F(8,55) & 0.1669 \\
Obs*R-squared & 11.67529 & Prob. Chi-Square(8) & 0.1663 \\
Scaled explained SS & 10.64892 & Prob. Chi-Square(8) & 0.2224 \\
\hline \hline
\end{tabular}

Hasil uji Breusch-Pagan-Godfrey tersebut menunjukkan bahwa probabilitas Chi-Square pada Obs*R-squared $>0,05$ yaitu sebesar 0,1663 Hal ini menunjukkan bahwa data bebas dari gejala heteroskedastisitas.

\section{Uji Autokorelasi}

Data tidak mengalami autokorelasi positif atau negatif tersebut bila hasil uji Durbin-Watson (d) sesuai dengan perbandingan $\mathrm{dU}<\mathrm{d}<(4-\mathrm{dU})$. $\mathrm{dU}$ dapat dilihat pada tabel Durbin-Watson pada signifikansi 5\% dengan rumus $(\mathrm{k}: \mathrm{N})$. k merupakan jumlah variabel bebas, dan $\mathrm{N}$ merupakan jumlah 
sampel dalam satu variabel. Hasil uji heteroskedastisitas dengan menggunakan aplikasi Eviews 9 adalah sebagai berikut :

Table 13

Tabel Hasil Uji Durbin-Watson

\begin{tabular}{|lr|}
\hline \hline Mean dependent var & -1.256120 \\
S.D. dependent var & 1.703260 \\
Akaike info criterion & 1.680615 \\
Schwarz criterion & 2.490196 \\
Hannan-Quinn criter. & 1.999550 \\
Durbin-Watson stat & 1.992567 \\
\hline \hline
\end{tabular}

Hasil uji Durbin-Watson menunjukkan bahwa nilai d adalah sebesar 1,992. Hasil d dibandingkan dengan dU dengan rumus $\mathrm{k} ; \mathrm{N}(8: 64)$ yang merupakan data dari delapan variabel selama 4 tahun. Nilai dU pada tabel adalah sebesar 1,8844 sehingga perbandingan antara $\mathrm{d}$ dan $\mathrm{dU}$ memenuhi syarat $\mathrm{dU}<\mathrm{d}<$ (4-dU), yaitu $1,8844<1,992<2,1156$. Hal ini menunjukkan bahwa data tidak mengalami autokorelasi.

Uji asumsi klasik yang dilakukan terhadap data perusahaan yang tergolong Manipulator menunjukkan bahwa tidak ada masalah terhadap normalitas, multikolinieritas, heterokedastisitas dan autokorelasi data. Hal ini mengindikasikan bahwa data memiliki ketepatan dalam estimasi, konsisten dan tidak bias sehingga dapat dilakukan analisis regresi untuk menguji hipotesis penelitian.

\section{Hasil Uji Hipotesis}

Tabel 14

Hasil Uji Regresi Linier Sederhana

\begin{tabular}{lccc}
\hline $\begin{array}{l}\text { Regression } \\
\text { Variables }\end{array}$ & Coefficient & t-statistic & Prob. \\
\hline Constant & -1.908728 & -8.035698 & 0.0000 \\
$\begin{array}{l}\text { DSRI (H1) } \\
\text { Adjusted } \\
\text { Adjusted R }\end{array}$ & 0.675442 & 3.134543 & 0.0030 \\
\hline Constant & & 0.711572 & \\
GMI (H2) & -1.844601 & -5.527563 & 0.0000 \\
Adjusted R & 0.053662 & 1.892680 & 0.0646 \\
\hline Constant & & 0.067597 & \\
AQI (H3) & -1.589807 & -5.491310 & 0.0000 \\
Adjusted R & 0.029853 & 1.274593 & 0.2087 \\
\hline Constant & & 0.066292 & \\
SGI (H4) & -2.113004 & -7.136727 & 0.0000 \\
\hline
\end{tabular}

\begin{tabular}{|c|c|c|c|}
\hline $\begin{array}{l}\text { Regression } \\
\text { Variables } \\
\end{array}$ & Coefficient & t-statistic & Prob. \\
\hline Adjusted $\mathrm{R}^{2}$ & & 0.711666 & \\
\hline Constant & -1.889614 & -8.148792 & 0.0000 \\
\hline DEPI (H5) & 0.614656 & 3.139886 & 0.0029 \\
\hline Adjusted $\mathrm{R}^{2}$ & & 0.711742 & \\
\hline Constant & -0.946556 & -3.445550 & 0.0012 \\
\hline SGAI (H6) & -0.245288 & -1.261893 & 0.2132 \\
\hline Adjusted $\mathrm{R}^{2}$ & & 0.066270 & \\
\hline Constant & -2.382001 & -9.451014 & 0.0000 \\
\hline TATA (H7) & 5.763035 & 4.888521 & 0.0000 \\
\hline Adjusted $\mathrm{R}^{2}$ & & 0.768822 & \\
\hline Constant & -0.678082 & -2.485287 & 0.0166 \\
\hline LVGI (H8) & -0.536898 & -2.353949 & 0.0228 \\
\hline Adjusted $\mathrm{R}^{2}$ & & 0.688054 & \\
\hline
\end{tabular}

1. Pengaruh Days Sales in Receivable Index (DSRI) terhadap Manajemen Laba

Hasil dari pengujian H1 menggunakan regresi linier sederhana menunjukkan hubungan yang signifikan antara DSRI dengan manajemen laba. Adapun DSRI mempengaruhi laba manajemen sebesar $71,16 \%$ dengan setiap peningkatan $1 \%$ DSRI maka manajemen laba akan meningkat sebesar 0.675442 satuan. Berdasarkan hasil tersebut, maka hipotesis pertama terdukung.

Hasil ini menunjukkan bahwa perusahaan yang tergolong sebagai manipulator memanipulasi piutang sehingga meningkatkan pendapatan perusahaan. Manipulasi terhadap piutang perusahaan dapat berupa pengakuan piutang sebagai pendapatan (Priantara, 2013) sehingga pernyataan pendapatan pada laporan keuangan tentunya lebih besar sehingga menarik investor dan kreditor untuk memberikan bantuan modal. Penelitian ini menggunakan laporan keuangan perusahaan sektor property, real estate dan konstruksi bangunan yang cenderung memiliki piutang cukup besar. Hal ini tentu saja akan dimanfaatkan perusahaan untuk membuat laporan keuangan dengan pendapatan yang besar dengan hanya memanipulasi beberapa piutangnya. Hasil penelitian ini sejalan dengan hasil penelitian yang dilakukan oleh Beneish (1999) dan Repousis (2016) yang menemukan bahwa DSRI berpengaruh signifikan terhadap manajemen laba dalam mendeteksi kecurangan laporan keuangan. 
2. Pengaruh Gross Margin Index (GMI) terhadap Manajemen Laba

Hasil dari pengujian $\mathrm{H} 2$ menggunakan regresi linier sederhana menunjukkan hubungan yang tidak signifikan antara GMI dengan manajemen laba. Pengaruh GMI terhadap laba manajemen bahkan bernilai $6,75 \%$ dengan setiap peningkatan $1 \%$ GMI maka manajemen laba akan meningkat sebesar 0.053662 satuan. Berdasarkan hasil tersebut, maka hipotesis kedua tidak terdukung.

Hasil ini menunjukkan bahwa profitabilitas perusahaan tidak berpengaruh terhadap perusahaan yang tergolong manipulator untuk memanipulasi pendapatannya. Menurut Handayani (2016) profitabilitas perusahaan berpengaruh terhadap adanya manipulasi dengan meratakan pendapatan perusahaan. Semakin tinggi pendapatan, maka perusahaan akan memanipulasinya agar sesuai dengan target perusahaan dan mengalokasikan sisanya untuk menutupi periode yang pendapatannya rendah. Namun, penelitian ini menggunakan sampel perusahaan sektor property, real estate dan konstruksi bangunan yang profitabilitasnya cenderung stabil sehingga manipulasi pada profitabilitas tidak dilakukan oleh manajemen perusahaan.

Perusahaan pada sektor ini memiliki profitabilitas yang stabil karena bergerak untuk menyediakan produk yang merupakan kebutuhan pokok masyarakat. Peningkatan profitabilitasnya akan sejalan dengan meningkatnya kebutuhan akan property, real estate dan bangunan-bangunan lainnya seiring dengan lajunya pertumbuhan penduduk di Indonesia. Hasil penelitian ini tidak sejalan dengan hasil penelitian yang dilakukan oleh Beneish (1999) dan Repousis (2016) yang menemukan bahwa GMI berpengaruh signifikan terhadap manajemen laba dalam mendeteksi kecurangan laporan keuangan.

\section{Pengaruh Asset Quality Index (AQI) terhadap Manajemen Laba}

Hasil dari pengujian $\mathrm{H} 3$ menggunakan regresi linier sederhana menunjukkan hubungan yang tidak signifikan antara AQI dengan manajemen laba. Pengaruh AQI terhadap manajemen laba hanya sebesar $6,63 \%$ dengan setiap peningkatan $1 \%$ AQI maka manajemen laba akan meningkat sebesar 0.0298530 satuan. Berdasarkan hasil tersebut, maka hipotesis ketiga tidak terdukung.

Hasil ini menunjukkan bahwa adanya peningkatan proporsi aset perusahaan tidak berpengaruh terhadap adanya manipulasi laporan keuangan. Manipulasi aset dalam laporan keuangan biasanya dilakukan dengan melebih-lebihkan pencatatat aset namun mengefisienkan kewajiban sehingga perusahaan terlihat kuat dalam segi finansial (Priantara, 2013). Penelitian ini menggunakan sampel perusahaan sektor property, real estate dan konstruksi bangunan dimana aset tetap tidak bergerak menjadi aset lancar bagi perusahaan. Dengan begitu, manajemen akan lebih sulit untuk mencatat peningkatan aset lancar yang besar ini secara berlebihan tanpa meningkatkan nilai kewajibannya. Hal ini disebabkan oleh semakin besar aset perusahaan, maka otomatis kewajiban perusahaan juga akan meningkat.

Peningkatan proporsi aset pada perusahaan sektor property, real estate dan konstruksi bangunan pada umumnya membutuhkan waktu yang lama untuk pembangunan aset. Dengan begitu, peningkatan proporsi aset akan meningkat secara perlahan sehingga manajemen tidak akan tertarik untuk memanipulasi proporsi peningkatan aset perusahaan. Hasil penelitian ini tidak sejalan dengan hasil penelitian yang dilakukan oleh Beneish (1999) dan Repousis (2016) yang menemukan bahwa AQI berpengaruh signifikan terhadap manajemen laba dalam mendeteksi kecurangan laporan keuangan.

\section{Pengaruh Sales Growth Index (SGI) terhadap Manajemen Laba}

Hasil dari pengujian $\mathrm{H} 4$ menggunakan regresi linier sederhana menunjukkan hubungan yang signifikan antara SGI dengan manajemen laba. Pengaruh SGI terhadap manajemen laba sebesar $71,16 \%$ dengan setiap peningkatan $1 \%$ SGI maka manajemen laba akan meningkat sebesar 0.785779 satuan. Berdasarkan hasil tersebut, maka hipotesis keempat terdukung.

Hasil ini menunjukkan bahwa ada pengaruh antara pertumbuhan penjualan terhadap manipulasi pendapatan pada laporan keuangan. Beneish (1999) mengatakan bahwa kebutuhan perusahaan untuk mengurangi beban pajak yang besar adalah dengan memanipulasi pertumbuhan penjualan. Penelitian ini menggunakan sampel perusahaan sektor property, real estate dan konstruksi bangunan dimana memiliki pertumbuhan penjualan yang lebih rendah bila dibandingkan dengan sektor yang lain. Dengan kondisi pertumbuhan penjualan yang rendah, sedangkan pajak penjualan sektor ini yang besar maka manajemen harus memanipulasi pertumbuhan penjualannya agar pajak yang dikenakan menjadi 
lebih kecil. Sesuai dengan teori agensi, manipulasi pertumbuhan penjualan yang dilakukan manajemen bertujuan untuk meningkatkan kesejahteraan mereka. Di sisi lain, mereka harus tetap mempertimbangkan agar laporan keuangan menarik bagi investor. Hasil penelitian ini sejalan dengan hasil penelitian yang dilakukan oleh Beneish (1999) dan Repousis (2016) yang menemukan bahwa SGI berpengaruh signifikan terhadap manajemen laba dalam mendeteksi kecurangan laporan keuangan.

\section{Pengaruh Depreciation Index (DEPI) terhadap Manajemen Laba}

Hasil dari pengujian H5 menggunakan regresi linier sederhana menunjukkan hubungan yang signifikan antara DEPI dengan manajemen laba. Pengaruh DEPI terhadap manajemen laba sebesar $71,17 \%$ dengan setiap peningkatan $1 \%$ DEPI maka manajemen laba akan meningkat sebesar 0,614656 satuan. Berdasarkan hasil tersebut, maka hipotesis kelima terdukung.

Hasil ini menunjukkan bahwa depresiasi aset berpengaruh terhadap adanya manipulasi laporan keuangan. Salah satu cara agar pendapatan terlihat meningkat adalah dengan memperlambat laju depresiasi (Beneish, 1999).. Penelitian ini menggunakan sampel perusahaan sektor property, real estate dan konstruksi bangunan dimana aset tetap tidak bergerak dikategorikan sebagai aset lancar bagi perusahaan. Depresiasi akan dihapuskan seiring dengan penjualan yang dilakukan oleh perusahaan. Bila depresiasi dapat diperlambat, maka otomatis nilai aset yang akan dijual akan bertambah sehingga pendapatan dari penjualan juga akan meningkat. Sesuai dengan teori agensi, hal ini tentu saja akan dimanfaatkan manajemen untuk keuntungan manajemen sekaligus membuat laporan keuangan terlihat lebih menarik bagi investor

Hasil penelitian ini tidak sejalan dengan hasil penelitian yang dilakukan oleh Repousis (2016), namun sejalan dengan hasil penelitian yang dilakukan oleh Beneish (1999) yang menemukan bahwa DEPI berpengaruh signifikan terhadap manajemen laba dalam mendeteksi kecurangan laporan keuangan.

\section{Pengaruh Selling, General and Administratif Index (SGAI) terhadap Manajemen Laba}

Hasil dari pengujian H6 menggunakan regresi linier sederhana menunjukkan hubungan yang tidak signifikan antara SGAI dengan manajemen laba. Pengaruh SGAI terhadap manajemen laba hanya bernilai $6,62 \%$ dengan setiap peningkatan $1 \%$ SGAI maka manajemen laba akan berkurang sebesar 0.245288 satuan. Berdasarkan hasil tersebut, maka hipotesis keenam tidak terdukung.

Hasil ini menunjukkan bahwa nilai beban penjualan, umum dan administratif tidak berpengaruh terhadap adanya manipulasi pada laporan keuangan. Semakin besar beban penjualan, umum dan administratifnya, maka semakin besar pula pendapatan perusahaan (Kurnia, 2017). Penelitian ini menggunakan perusahaan sampel perusahaan sektor property, real estate dan konstruksi bangunan dimana nilai beban penjualan, umum dan administratif relatif kecil dibandingkan dengan nilai penjualannya. Kecilnya beban ini bila dimanipulasi maka tidak akan berpengaruh banyak untuk meningkatkan pendapatan perusahaan. Hasil penelitian ini tidak sejalan dengan hasil penelitian yang dilakukan oleh Beneish (1999) dan Repousis (2016) yang menemukan bahwa SGAI berpengaruh signifikan terhadap manajemen laba dalam mendeteksi kecurangan laporan keuangan.

\section{Pengaruh Total Accrual to Total Assets Index (TATA) terhadap Manajemen Laba}

Hasil dari pengujian $\mathrm{H} 7$ menggunakan regresi linier sederhana menunjukkan hubungan yang signifikan antara TATA dengan manajemen laba. TATA mempengaruhi manajemen laba sebesar $76,88 \%$ dengan setiap peningkatan $1 \%$ TATA maka manajemen labaakan meningkat sebesar 5,763035 satuan. Berdasarkan hasil tersebut, maka hipotesis ketujuh terdukung.

Hasil ini menunjukkan bahwa volume penghasilan yang dihasilkan dari pendapatan akrual mempengaruhi terjadinya manipulasi pendapatan pada laporan keuangan. Pendapatan akrual dilaporkan dalam bentuk laporan laba rugi pada periode dimana penghasilan dihasilkan tanpa melihat apakah kas sudah diterima atau belum dari pelanggan selama periode tersebut. Penelitian ini menggunakan sampel perusahaan sektor property, real estate dan konstruksi bangunan yang pada umumnya memiliki pendapatan yang besar dalam satu proyek yang dihasilkan. Hal ini lah yang menjadi motivasi bagi manajemen untuk membuat laporan keuangannya agar terlihat lebih menarik bagi investor. Dengan pengakuan pendapatan akrual tersebut, manajemen memiliki kesempatan untuk mencatat pendapatan tersebut melebihi pendapatan sesungguhnya agar 
pernyataan pendapatan pada laporan keuangan terlihat lebih tinggi. Hasil penelitian ini tidak sejalan dengan hasil penelitian yang dilakukan oleh Repousis (2016), namun sejalan dengan hasil penelitian yang dilakukan oleh Beneish (1999) yang menemukan bahwa TATA berpengaruh signifikan terhadap manajemen laba dalam mendeteksi kecurangan laporan keuangan.

\section{Pengaruh Leverage Index (LVGI) terhadap Manajemen Laba}

Hasil dari pengujian H8 menggunakan regresi linier sederhana menunjukkan hubungan yang signifikan antara LVGI dengan manajemen laba. Pengaruh LVGI terhadap manajemen laba bernilai $68,81 \%$ dengan setiap peningkatan $1 \%$ LVGI maka manajemen laba akan berkurang sebesar 0,536898 satuan. Berdasarkan hasil tersebut, maka hipotesis kedelapan terdukung.

Hasil ini membuktikan bahwa proporsi hutang berpengaruh terhadap manipulasi pendapatan pada laporan keuangan. Semakin tinggi nilai leverage perusahaan mengisyaratkan bahwa semakin banyak aset perusahaan yang dibiayai dengan hutang (Darmadji \& Fakhrudin, 2012). Oleh karena itu, perusahaan akan memanipulasi hutangnya agar tidak terlalu besar sehingga rasio leverage perusahaan terlihat rendah dan menunjukkan bahwa kondisi perusahaan sedang baik-baik saja.

Penelitian ini menggunakan sampel perusahaan sektor property, real estate dan konstruksi bangunan yang tentunya memiliki nilai hutang yang cukup besar untuk membantu membiayai operasional perusahaan. Hal ini tentu saja akan menuntut manajemen memanipulasi hutang agar laporan keuangan mampu menarik investor untuk membantu modal perusahaan. Hasil penelitian ini tidak sejalan dengan hasil penelitian yang dilakukan oleh Repousis (2016), namun sejalan dengan hasil penelitian yang dilakukan oleh Beneish (1999) yang menemukan bahwa LVGI berpengaruh signifikan terhadap manajemen laba dalam mendeteksi kecurangan laporan keuangan.

\section{Kesimpulan dan Saran}

\section{Kesimpulan}

Berdasarkan hasil yang didapatkan dari pengolahan data menggunakan aplikasi Eviews 9 dapat diambil kesimpulan sebagai berikut :
1. Days Sales in Receivable Index (DSRI) berpengaruh signifikan terhadap manajemen laba dalam mendeteksi kecurangan laporan keuangan pada perusahaan sampel yang terdaftar di Bursa Efek Indonesia.

2. Gross Margin Index (GMI) tidak berpengaruh signifikan terhadap manajemen laba dalam mendeteksi kecurangan laporan keuangan pada perusahaan sampel yang terdaftar di Bursa Efek Indonesia.

3. Asset Quality Index (AQI) tidak berpengaruh signifikan terhadap manajemen laba dalam mendeteksi kecurangan laporan keuangan pada perusahaan sampel yang terdaftar di Bursa Efek Indonesia.

4. Sales Growth Index (SGI) berpengaruh signifikan terhadap manajemen laba dalam mendeteksi kecurangan laporan keuangan pada perusahaan sampel yang terdaftar di Bursa Efek Indonesia.

5. Depreciation Index (DEPI) berpengaruh signifikan terhadap manajemen laba dalam mendeteksi kecurangan laporan keuangan pada perusahaan sampel yang terdaftar di Bursa Efek Indonesia.

6. Selling, General and Administratif Index (SGAI) tidak berpengaruh signifikan terhadap manajemen laba dalam mendeteksi kecurangan laporan keuangan pada perusahaan sampel yang terdaftar di Bursa Efek Indonesia.

7. Total Accrual to Total Assets Index (TATA) berpengaruh signifikan terhadap manajemen laba dalam mendeteksi kecurangan laporan keuangan pada perusahaan sampel yang terdaftar di Bursa Efek Indonesia.

8. Leverage Index (LVGI) berpengaruh signifikan terhadap manajemen laba dalam mendeteksi kecurangan laporan keuangan pada perusahaan sampel yang terdaftar di Bursa Efek Indonesia.

Saran

Hasil penelitian menunjukkan bahwa DSRI, SGI, DEPI, TATA, dan LVGI berpengaruh signifikan terhadap manajemen laba. Sedangkan GMI, AQI, SGI, dan SGAI tidak berpengaruh terhadap manajemen laba dalam mendeteksi kecurangan laporan keuangan. Hal ini disebabkan karena data yang menunjukkan bahwa perusahaan sampel yang tergolong sebagai manipulator lebih banyak dipengaruhi oleh DSRI, SGI, DEPI, TATA, dan LVGI. Dengan adanya keterbatasan penelitian, maka disarankan untuk penelitian selanjutnya agar 
menambah jumlah sampel penelitian ke sektor-sektor perusahaan lain yang ada di Bursa Efek Indonesia sehingga cakupan penelitian lebih luas dan hasil penelitian sejenis semakin baik.

\section{Daftar Pustaka}

Association of Certified Fraud Examiners (ACFE). (2016). Survai Fraud Indonesia 2016. Jakarta: ACFE Indonesia Chapter.

Beneish, M. D. (1999). The Detection of Earnings Manipulation. Financial Analysts Journal, 24-36.

Darmadji, M., \& Fakhrudin, M. (2012). Pasar Modal di Indonesia. Jakarta: Salemba Empat.

Ghozali, I. (2013). Analisis Multivariat dan Ekonometrika : Teori, Konsep, dan Aplikasi dengan EVIEWS 9. Semarang: Badan Penerbit Universitas Diponegoro.

Handayani, S. (2016). Analisis Faktor-Faktor yang Berpengaruh terhadap Perataan Laba. Jurna Penelitian Ekonomi dan Akuntansi, 225-244.

Ikatan Akuntan Indonesia. (2012). Standar Akuntansi Keuangan. Jakarta: Salemba Empat.
Jensen, M., \& Meckling, W. (1976). Theory of The Firm: Managerial Behavior, Agency Cost, and Ownership Structure. Jurnal of Financial Economics, 305-360.

Kasmir, S. (2013). Analisis Laporan Keuangan. Jakarta: PT Raja Grafindo Persada.

Kurnia, Y. (2017). Pengaruh Biaya Pemasaran Terhadap Volume Penjualan. Journal Of Engineering and Sustainable Technology, 168-176.

Priantara, D. (2013). Fraud Auditing \& Investigation. Jakarta: Mitra Wacana Media.

Repousis, S. (2016). Using Beneish model to detect corporate financial statement fraud in Greece. Journal of Financial Crime, 1063-1073.

Skousen, C. J., Smith, K. R., \& Wright, C. J. (2009). Detecting and predicting financial statement fraud: The effectiveness of the fraud triangle and SAS No. 99. Corporate Governance and Firm Performance (Advances in Financial Economics), 53-81.

Tuanakotta, T. (2013). Mendeteksi Manipulasi Laporan Keuangan. Jakarta: Salemba Empat. 